\title{
'n OORSIG OOR DIE DIAKONIOLOGIESE ROL VAN DIE GEREFORMEERDE BELYDENISSKRIFTE IN KERKWEES 1
}

\author{
B. Spoelstra \\ Departement Diakoniologie \\ Potchefstroomse Universiteit vir $\mathrm{CIO}$ \\ POTCIIEFSIROOM
}

\begin{abstract}
While theology usually concentrates on the history and content of the Reformational creeds, less systematised infonnation is available about the ministry and service which these creeds should fulfil in the life of the church as believers. This study points 10 a consistent continuity in the way confessions of faith were used by the carly Christians, the Reformers and in the creeds of the Reformation. The content of the Heidelberg Catechism in particular bears a remarkable correspondence to the tradition in the early churches. Creeds can only be confessions of faith if they communicatc the revelation from Scriptures. If creeds function thus, the current widespread indifference to the practical use of even the Heidelberg Catechism in the practical world of the church must be ascribed to the illegitimate distincrion which Rationalism draws between pradical (or subjective) and docirinal (or objective) theology.
\end{abstract}

\section{INLIIIDING;}

Daar is baie geskrywe oor die ontstaan, inhoud, doel en waarde van die belydenisskrifte (vgl. hyvoorbeeld Polman, s.j. 1:9-44). Bavinck sr. het onderskei tussen belydenis en die bely van geloof (Zuidema, s.j:88). In die Nederlandse literatuur skemer iets tweeslagtigs deur tussen geloof en belydenisskrifte. Hiervolgens hoort belydenisskrifte by 'n objektiewe "kerk" as leer van die kerk as instituut (vgl. byvoorbeeld Zuidema, s.j: 88-90; Velema, 1973:31; Polman, 1956:551 e.v.), terwyl gelowiges hulle geloof individueel bely.

\footnotetext{
1 Hicrdic artikel vorm decl van dic recks artikels $(x)$ r die belydenis en dic belydenisskrifte. Kyk ook In dic Skriflig 25(1)1991.
} 
Die dubbelpraat gaan verder wanneer in die kerk as vergadering van gelowiges (HK Sondag 21; NGB 27-29) "onbelede geloof en nietgeloofde belijdenis" teenoor mekaar te staan kom (vgl. Zuidema, s.j.:88). Van Itterzon skryf Belijnd belijden (1971) en Velema rig hom tot die kerkvolk met Blijven belijden (1973). Tog is uit beide boeke nie duidelik hoe die belydenisskrifte prakties by die gemeente funksioneer nie. Die funksionering van die Drie Formuliere van Eenheid in kerkwees as bediening van wat God sê, verdien dus aandag. Daarmee is die diakoniologiese rol van die belydenisskrifte aan die orde.

Die vraag is ook of alle belydenisskrifte dieselfde karakter dra en eners in die bediening van die kerk (gemeente) funksioneer. Sou die vroegste kerke byvoorbeeld geen belydenisskrifte gebruik het nie en die gereformeerde kerke met die Reformasie 'n ander weg opgegaan het?

\section{BELYDENISSKRIFTE EN GEI OWIGE KERKWEES}

Wat bedoel gereformeerde teoloë deur in die enkelvoud te sê "dat de kerk een belijdende kerk dient te zijn" (Van Itterzon, 1971:6)? Indien die kerk soos die belydenis (HK Sondag 21; NGB 27-29) en Calvyn (1951:317e.v.) dit stel, gelowige mense is, verwag 'n mens minder verwarring en groter harmonie tussen begrippe soos geloof, belydenis, geloofsbelydenis, belydenisskrifte, kerk, gemeente, belydende kerk, kerk met 'n belydenis en (onder voorbehoud) die "belydeniskerk" (vgl. Polman, 1956:551 e.v.). Die dualisme tussen kerk (as instituut) en gemeente (vgl. Polman, t.a.p, 54 e.v.) skep die indruk dat die leer objektief by die kerk "as instituut" behoort. Die moderne kerkbegrip het 'n neiging om in 'n statiese instituut te stol (Spoelstra, 1986). Daarteenoor leer die Skrif en die belydenisskrifte dat ware geloof iemand aan Christus verbind en daarom 'n plek in die gemeente (kerk) gee.

Geloof staan en val met sekerheid (vgl. HK Sondag 7: gewisse ... vaste). Geloofsbelydenisse wil sekerhede wat in die Skrif geopenbaar is, verwoord. Geloofsbelydenisse is "faith's affirmations about God. They are therefore radically different from all rational metaphysics". Omdat God verborge is, maar Homself bekend gemaak het, dra geloof 'n "unfathomable character" (Aulén, 1960:78). Sekerheid van geloof staan nie los van wat geglo word nie, maar berus op die inwendige persoonlike oortuiging wat die Heilige Gees met die Woord in 'n mens werk (Ibid:87, vgl. HK Sondag 7, NGB 2). Geloof is in beginsel iets vasstaande en definitief. Daar is nie iets soos 'n vae en "indefinite faith" nie (Aulén, 1960:59). Tog máak bewegings soos EE3 van "geloofsekerheid" 'n subjektiewe kriterium buite geloofsinhoud en belydenisskrifte om. 
"Geloofsoortuiginge" wat uit algemene belydenisskrifte ontstaan of hulle daarop beroep, moet van die belydenisskrifte onderskei word (Delleman et al., 1966;14). Die skeuring in die GKN gedurende 1944 het grotendeels plaasgevind toe teologiese interpretasies van die leer van die doop met die belydenis vereenselwig is. Op hierdie foutiewe bediening van die Drie Formuliere van Eenheid gaan ons hier nie verder in nie.

Die plek van belydenisskrifte in die aksente op geloof wat deesdae in "gemeentebou" gelê word, is nie altyd duidelik nie. Gaan dit om geloof wat in die belydenisskrifte bely word, of om belydenisskrifte wat vryblywend aan 'n objektiewe "kerk" maar nie aan die "lidmate" behoort nie? Velema (1973:36) gebruik 'n beeld van A.A. van Ruler: "De kerk is een koor, dat in de wereld staat te zingen, als ik belijdenis doe, ga ik bij dat koor staan en ga ik meezingen." Die vriag is egter in hoeverre die Drie Formuliere van Eenheid vandag nog die musiek is waarop gelowiges hulle lied van geloof sing of werklik die gemeente se antwoord op die Woord (König, 1966:29) is.

Geloof is ' $n$ gawe van God en 'n daad van ' $n$ mens. Werklike geloof wat mense tot 'n kerk saambind, is iets anders as om ja te sê vir die leer van die kerk of om instemming te betuig met die inhoud van die Bybel (Velema, 1973:22). Om kerk te wees moet mense die geloof self bely. Besef mense nog dat die Formuliere van Eenheid'n dienende rol het om kerkwees, dit wil sê eenheid in geloof met ander te beseël?

Kuitert sê dalt by Rome die "kerk" die waarheid beskerm, terwyl by die Reformasie die "waarheid" in die Woord die kerk voorafgaan (Kuitert, 1972:68).

The church as a body of believers confesses its faith as a testimony of its faith in God triune and as a witness to the world ... The church that lives out of the Word of God confesses its communal faith in its creeds, calechismus and confessions ... that unites the members of the church internatlly and function as a witness to those outside ... (Klooster, 1977:22).

Die vraag is of hierdie stelling in praktyk verwesenlik word en of "lidmate" nie baie keer soos passasiers in 'n skip vaar wat belydenisskrifte bloot as sy vlag gebruik nie. Belydenisse is nie 'n stokperdjie vir teoloë nie (Polman, s.j. :89 e.v.). Tog slaan sommige teoloë belydenisskrifte in hulle verwysingsraamwerk hoog aan, terwyl ander en moontlik selfs gemeentelede dit nie so hoog reken nie (Van Genderen, 1971; Van der linde, 1975; Polman, 1978). Is die belydenisskrifte werklik Fomuliere van Eenheid, die enigste "geldig accoord van kerkelijke gemeenschap" (Polman, s.j. :89-91) of staan belydenisskrifte net op 'n kerklike inventaris (Van't Spijker 1974:35) van 'n kerkorde of "konstitusie"? Is dit korrek om sito-sito te sê dat die "drie Afrikaanse kerke" of selfs die GKSA in algemene sinodale verband, dieselfde belydenisskrifte het en daarom "een" is? Mense kan so maklik soos Van Oosterzee sê: "Christen is my naam. 
Gereformeerd is my bynaam" (in Van't Spijker,1974:37). Die belydenisskrifte beantwoord slegs aan hulle naam wanneer hulle 'n diakoniologiese rol by die "lidmate" speel.

Talle gereformeerdes onderskei vandag tussen kerk as instituut en kerk as organisme (Kuyper, 1909:191 e.v., 204, 215). Belydenisskrifte sou by die "kerk as instituut" hoort en 'n "belydeniskerk" veroorsaak. Wie minder erns met belydenisskrifte maak, noem hulleself "belydende kerk" (Schleiermacher en Barth). Die "belydende kerk" sou dan onder leiding van die Gees gedurig die subjektiewe geloof in Christus aktualiseer. Tereg wys Velema (1973:38 e.v.) hoe relatief die terme belydeniskerk en belydende kerk is. Die belydende kerk het ook belydenisskrifte nodig en die belydeniskerk kan slegs bely wat die Skrif openbaar om belydende kerk te kan wees. Belydenisskrifte, geloofsbelydenis en kerkwees staan en val by "eenheid in die ware geloof" (HK Sondag 21; Spoelstra, 1989a:297-308).

Min empiriese studies het al vasgestel waarom sommige gereformeerdes 'n afkeer van vaste belydenisskrifte het (vgl. Velema, 1973:38). Sou die taal, styl of die inhoud van die belydenisskrifte so veel van die Bybel verskil dat sommige nie die Bybel in die belydenisskrifte kan terugvind nie? Sou blote vooroordeel belydenisskrifte in 'n kluis toesluit? Veroorsaak bepaalde filosofiese voorveronderstellings of ervaring met kategoriese hantering van belydenisskrifte dat die verband tussen die Bybel en belydenis verlore gaan? Hierdie negatiewe houding kan nie hier uitgepluis word nie.

Devaluasie van die belyde geloof met 'n onverskillige houding teenoor die sogenaamde kategismuspreke (Spoelstra, 1990 a en b), die degradering van die Heidelbergse Kategismus tot ' $n$ kerklike vak in kategese en die toenemende onverskilligheid teenoor die leer en die belydenisskrifte, makk dit noodsaaklik om na die bedieningsrol van die belydenisskrifte in dinamiese kerkwees te kyk. Geloof is altyd vir die gemeente van die Here 'n "totalitaire zaak. Geloven is niet ... ja zeggen op de belijdenis en daarmee klaar. Geloven is een levensinstelling" en lewenshouding (Velema, 1973:63). Kerk is 'n eenheid van mense wat dieselfde glo (HK Sondag 21; NGB 27-29; Snyman, 1948:2; 1977:24; Spoelstra, 1989 a:5).

\section{DIE GEBRUIK VAN BEL.YDENISSKRIFIE IN DIE VROEë CHRISTELIKE KERKE}

Die verkondiging en kategese in die jong Christelike kerke sluit aan by die OuTestamentiese tradisie. In die Ou Testament funksioneer leerinhoude, maar nie belydenisskrifte as sodanig nie. Die Nuwe-Testamentiese kerke gee aan die Wet ook sy plek in die verbondsonderwys. Die Wet verkry egter 'n nuwe aksent in Jesus Christus 
(Heb. $4: 14 ; 8: 6-13$ ). In nou verband met die Woord praat Hebreërs $4: 14$ van die eenstemmige belydenis (homologia). Die Nuwe Testament gee "various types of confessions but not a fixed verbal form" weer. Nietemin is daar 'n innerlike konstantheid in formuleringe. Die "evangelie" word selfs "tradisie" genoem en in die vorm van 'n geloofsbelydenis in 1 Korintiërs 15:3-8 saamgevat (Conzelmann, 1966:16-18).

Die Nuwe-Testamentiese belydenisformules is "kommentierende Kurzfassungen des Verkündigten und Geglaubten" waarmee die "kerugmatisch-kirchlicher Einheit" as geskiedenis en waarheid bedien is (Von Günter, 1985:786). Dodd (1966:55) se onderskeiding tussen "preaching" (keryssein) en "teaching" (didaskein) (1966:7-9), sonder dat 'n belydenistradisie ontstaan het, is hoogs omstrede (Green, 1970:204).

Die kern van die eerste Nuwe-Testamentiese belydenisse was dat Jesus die Christus en Here is (Klooster, 1977:40; Velema, 1973:104; König, 1977:52; 1982:359, vergelyk Matt. 10:32; 16:16; Luk. 12:8 e.v.; Joh. 9:22, 12:42; Hand. 17:7; Rom. 10:9; 1 Kor. 9:13; Fil. 2:11; Heb. 3:1, 4:14, 13:15; 1 Joh. 4:15). "Omdat Hy die Here is, het hy geen vryblywendheid toegelaat nie." Wie Jesus as die Here bely, neem 'n "lewensbeslissing" en hierteenoor kan geen tweede alternatiewe belydenis in die Nuwe Testament bestaan nie (König, 1982:359). Die belydenis sou natuurlik al meer in 'n vaste formule saamgevat kan word.

Die "leer" was van die begin af vir die jong kerke belangrik (Matt. 28:19 e.v.; Joh. 7:16,17; Hand. 2:1; 2 Kor. 9:13; Tim. 1:3,10, 3:2, 4:6,11,13,16; 1 Tim. 2:2,24, 3:10, 4:2,3; Titus 1:9,11, 2:1,7,10 ens.). Die apostels wys dwaalleer en "vreemde leer" as lewensgevaarlik vir die jong gemeentes af (Rom. 16:17; Ef. 4:14; 2 Joh. 9,10; Op. 2:24). Die opmerklike is: "Nirgends spielt Apostelautorität eine Rolle. Das Gewicht der Aussagen spricht für sich selbst und bedarf in der Regel keine Begründung" (Von Günter, 1985:793).

Belydenisskrifte as geskrewe dokumente het nie dadelik ontstaan nie. Selfs die Evangelie is eers mondeling oorgedra (Hagenbach, 1880:62) totdat uitgesoekte gedeeltes (vgl. Joh. 21:25) in die sinoptiese Evangelies te boek gestel is. Die "leer" wat aanvanklik in die openbaar (Hand. 2:22-36; 3:14-21; 4:10; 13:26-39; 17:2 e.v., 31; 18:5), kategese (Hand. 18:26) en pastoraat (Hand. 8:35; 16:31; 24;21;26:23) verkondig is, sentreer om die groot heilsdade van God, die kruis en opstanding uit die dode, die lewende Here en verlossing vir die gelowiges. Die latere Twaalf Artikels stem grootliks met hierdie eerste prediking ooreen. Die kern van die Twaalf Artikels (1 Kor. 15:3-8) word soos die Nagmaal (1 Kor. 11:23) in tradisie ontvang en onder die noemer "waarheid" (1 Tim 3:15), "geloof in God" en "leer" van die doop (1 Hebreërs 6:1-3) oorgelewer. 
Die Credo, Apostolicum of Symbolum Romanum het feitlik al in die jaar $200 \mathrm{~min}$ of meer sy beslag gehad (Schuize, 1990:13; Pont, 198lb:6) en het vir eeue 'n diakoniologiese rol vervul voor dit by Chalcedon in 451 amptelik as geloofsbelydenis erken is. Die Credo het die gelowiges as Christene getipeer (Hand. 11:26). Die proseliete het hulle geloof in die groot heilswaarhede rondom die name van God by hulle doop spoedig al meer met hierdie vaste formulering mondeling bevestig. Daarby is in die gemeente in die reël van die vraagvorm gebruik gemaak ... Glo jy aan God? ens. ... (Lohse, 1963:40) Op die vraag na God die Vader, het vrae oor die Seun en Gees gevolg. Daarop moes die dopeling telkens die Credo herhaal (Lohse, 1963:40; 1963:7; Van der Leeuw, 1946:61-66; Kurtz, s.j.:59; Doekes \& Deddens, 1963:7). Die ryke "variety contained in Scriptures finds expression in the living tradition of the church ... Tradition does not imply a lack in the biblical message; it emphasizes rather its inexhaustible richness" (Aulèn, 1960:71; vgl. Klooster, 1977:26).

Die Twaalf Artikels is dus as "Glaubensbekenntnis als die formelhafte zusammenfassen des christlichen Glaubens" en die rigsnoer van die geloof saam met die Wet en gebed vir kategese gebruik en daarmee is ware gelowiges van ketters en heidene onderskei. So het die Twaalf Artikels (Apostolicum) geleidelik die tweede dogma van die kerk geword (Lohse, 1963:40-43). 'n Kerksentriese liturgie beklemtoon die "konfessionele binding" met die Twaalf Artikels (Beukes, 1987:5) Die vroeë Christendom het nie 'n belydenisskrif gebruik om 'n organisasie te tipeer nie, maar die mense wat geloof met die "belydenisskrif" bely het, was die kerk. Die Twaalf Artikels was die taal waarmee die gemeente belydenis van geloof afgelê hęt, die geloof aktief gekontinueer het en die gemeente vir Nagmaalsgemeenskap gëidentifiseer het (vgl. Nel, 1981).

Die Credo het ook die volwasse doop, kinderdoop en Nagmaal liturgies verbind (Ursinus, 1886:13). Proseliete en kinders moes eers belydenis doen voordat hulle aan die Nagmaal (missa fidelium) en gemeente as corpus fidelium ten volle deel gekry het. Die Credo het verder liturgies die Nagmaal van die belydende gelowiges (missa fidelium) van die openbare samekoms van die gemeente saam met kinders en proseliete, die sogenaamde missa catechemenonm geskei (vgl. Beukes, 1987:12; Van der Leeuw, 1946:141-145; Van de Pol, 1931:37 e.v.). Die Credo was die taal van elke gelowige en van die ware Nagmaalsgemeente (vgl. Spoelstra, 1989a:336). Die gebruik van die Twaalf Artikels in ons erediensliturgie en in die ou Nagmaalsformulier herinner nog aan die gebruik van die Credo in die vroeë Christendom.

Die diakoniologiese sin van hierdie liturgiese gebruik van die Twaalf Artikels dreig om in allerlei nuwe liturgiese eksperimente verlore te gaan. Belydenis van geloof met die Twaalf Artikels mag nie in die erediens as 'n stuk onderwys funksioneer nie. 


\subsection{Nog 'n belydenisskrif te Nicea 325}

Gedurende die 3de eeu het die vraag dominerend na vore gekom: Wat dink jy van die Christus? (Van ltterzon, 1971: 5). Vir die doeleindes van hierdie artikel word die belydenisse van Arius en ander nie bespreek nie. Pas nadat die Christelike godsdiens openbare aansien verkry het, het die meerderheid biskoppe onder leiding van die keiser in die Konsilie van Nicea in 325 op bogenoemde vraag in ' $n$ belydenis antwoord gegee. In teenstelling met die direkte taal van die Twaalf Artikels, dra die belydenis van Nicea ' $n$ apologetiese karakter. Die Konsilie van Konstantinopel (381) en die kerkvader Athanasius het die belydenis oor die nature van God verder verwoord. "This means that theological formulae were discovered which were able to resolve the struggle, but theological terms are never able to overcome the religious difference itself" (Tillich, 1968:76).

Waar die Credo diakoniologies vir ' $n$ belydenisdaad in die gemeente gebore is, ontstaan te Nicea vir die eerste keer'n konfessie wat kerklik op gesag van die keiser aan die gemeente voorgeskryf word. Daarmee tree die moontlikheid van spanning tussen 'n offisiële belydenisstuk en geloof wat die gemeente daadwerklik bely na vore. Die Belydenis van Nicea is in leerstellige kontroverse en later by die Anglikane en in Nederland ook as wisselvorm vir die Twaalf Artikels in die erediens gebruik (Van der Leeuw, 1946:153,176).

\section{DIE GEIBRUIK VAN BELYIDINISSKRIFTE IN DIE REFORMASIE}

Die Roomse sakramentalisme gedurende die Middeleeue het die verkondiging, kategese en persoonlike geloofskeuse met 'n credo onnodig gemaak. Tog behou die Credo in meerdere of mindere mate as belydenisskrif sy liturgiese gebruik by die Mis. Dit gaan egter in die Misliturgie uit die mond van die gelowiges oor na die priesterkore. Die priester het namens die onmondige gemeente bely. Roma locuta, causa finita est (as Rome gepraat het, is die saak besleg). Die Protestante het hierdie oorlaat van verantwoordelikheid vir geloofsbelydenis aan die hiërargie as tirannie, gewetensdwang en vergryp aan die wese van gelowig-wees verwerp. Die Roomse kerk het egter verweer dat geloofsbelydenisse die Protestante verdeel het en roem dat wanneer die pous leer- en geloofsake beslis, die leek "moordende" twyfel, onsekerheid en verdeeldheid wat onder Protestante voorkom, gespaar word (Polman, s.j.:12). 


\subsection{Die Credo en Reformatoriese kategismusse}

Die Waldense wou reeds in die 12 de eeu deur middel van leerboekies, waar die pastor vrae stel en die katkisant antwoord, probeer om geloofsinhoude op sterkte van Skrifkennis oor te dra. Die Hussiete stel vroeg in die 15de eeu twee kategismusse op (Van 't Veer, 1942:149). Hierdie kategismusse sluit merkwaardig nou aan by die vroeë Kerke omdat daarin op die Credo, die Tien Gebooie, gebed en sakramente gekonsentreer word (Ibid:176 e.v.). Hierdie kategismusse of leerboeke was nie belydenisskrifte nie, maar was diensbaar tot geloofsbelydenis.

Die "grondskema" van reformatoriese kategismusse is daarom betekenisvol. Kategismusse moes diakoniologies dien om die "hoofsom" van die geloof oor te dra. Die Reformatore wou die gemeente gemeenskaplik getuienis laat gee van waarom hulle gedoop is, waarom hulle saam God aanbid en teenoor die wêreld 'n eie gemeenskap vorm (Van der Leeuw, 1946:173). Hierdie "eenheid van die kerk" volg op die verkondigingsgebeure (vgl. Van Aarde, 1987:339). Die "in-die-erediens-versamelde gemeente" (Van Aarde, 1989:470) maak die liggaam van Christus (universele kerk) sigbaar (Snyman, 1977:42 e.v.; Spoelstra, 1989a:5 e.v., 27 e.v., 224 e.v.) waar die gelowiges in die eenheid van ware geloof hulle God ontmoet (HK Sondag 21; NGB 27 29). Kerklike eenheid word derhalwe konfessioneel as eenheid in die waarheid bepaal (Van Aarde, 1989:465).

Luther en Calvyn se kategismusse sluit op hulle beurt ook net weer by die vroegste kerke in die Nuwe Testament en so by die Godsvolk van die Ou Testament aan. Die kategismusse leer basies net die heilsdade van God in die Twaalf Artikels, die Tien Gebooie (sedeleer) en gebed (gemeenskap met God). Uit die kontrovers met Rome voeg hulle die leer oor die sakramente by (Van 't Veer, 1942:176; De Villiers, 1957:107). Luther noem die Tien Gebooie doctrina doctrinarum (hoogste leer), die Twaalf Artikels simbool van die hoogste geskiedenis (historia historianum), die Onse Vader oratio orationum (hoogste gebed) en die sakramente ceremoniae ceremoniarum (Van 't Veer, 1942:190 e.v.). Daarom verbaas dit nie dat die Heidelbergse Kategismus presies aan hierdie skema en inhoud voldoen nie. Die credo van die vroeë Christelike kerke beheers Sondae 5 tot 24, die Tien Gebooie Sondae 1 tot 4 en 32 tot 44, die gebed bepaal Sondae 45 lot 52 terwyl die sakramente in Sondae 25 tot 30 saam met die sleutels van die hemelryk in Sondag 31 geleer word. Die "leer" en die Bybel staan nie dualisties langs mekaar nie. Die geloofsbelydenis wil net sê wat die Bybel openbaar.

Op die keper beskou, gebruik die Reformatore kategismusse om die Woord te bedien sodat mense geloofsbelydenis kan doen. Sowel Luther as Calvyn veronderstel dat die 
ouers en skole kragtens die doopbelofte hulle kinders in die Bybel sowel as in die leer sal onderrig en opvoed voordat hulle vir kategese aanmeld. Die Raad van Genéve het die burgers selfs met 'n eed daartoe verplig (vgl. De Villiers, 1957:107-112; Van 't Veer, 1942:62-140; Spoelstra, 1990a).

L.uther se twee kategismusse wat invioed op Calvyn uitgeoefen het, was glad nie as belydenisskrifte bedoel nie maar diakoniologies gerig om in die prediking, kategese en evangelisasie die Woord te bedien (Lohse, 1963:177, 185-189; Van 't Veer, 1942:147; De Villiers, 1957:107). Die belydenis van Augsburg wou iets anders as 'n kategismus wees en wou keiser Karel $V$ oor die bely van die geloof voorlig sonder om daarmee'n "Kirchentypen" te identifiseer (Lochse, 1963:178). Calvyn beoog dieselfde met sy brief aan Frans I in 1536 as voorwoord by die Institusie (Calvyn, 1951:15 e.v.). So 'n belydenisskrif verskil van 'n kategismus, hoewel 'n kategismus natuurlik ook geformuleerde geloof op grond van die Skrif wou kommunikeer.

Calvyn voorsien reeds in 1537 sy Instruction et confession de Foy (waarin kategismus en geloofsbelydenis gekoppel word) om die ware kerk te help om hulle geloof te bely (Van 't Veer, 1942:23; Calvyn, 1951:317-329). Gelowig-wees kom neer op gehoorsaam wees aan die Tien Gebooie en vereis bediening van die sleutels wat die Here gegee het om dissipline oor leer en lewe uit te oefen (Calvyn, 1951:320,325,328,374). Van Calvyn verskyn in 1541/42 'n tweede kategismus, verskillende uitgawes van sy Institusie en 'n Geneefse geloofsbelydenis. Hy oefen invloed uit op die ontstaan van die Franse Belydenis in die Sinode van Parys 1559. Die Nederlandse Geloofsbelydenis (1561) en Heidelbergse Kategismus (1563) makk hiervan dankbaar gebruik (vgl. Coetzee, 1947 :28-47; De Villiers, 1957:109 e.v.). Al die belydenisskrifte wat gedurende die Reformasie ontstaun (vg!. Schulze, 1990(9):11), moes soos die Heidelbergse Kategismus een doel dien: "Leer de natie haar doop verstaan ... en Kerk en Staat zijn gered" (Doekes in Dockes \& Deddens, 1963:8).

\subsection{Die funksie van die belydenisskrifte ten opsigtc van die Bybel}

Die Reformatore ken geen negatiewe houding teenoor die tradisie nie. Hulle deel nie die afkeer van die Anabaptiste en latere piëtistiese en vrysinnige groepe teen die ouer en ekumeniese belydenisskrifte nic (Aulen, 1960:70; vgl. Polman, s.j.:29 in verband met Calvyn se stryd met Caroli).

Die Skrif bly nomma normans, die belydenisskrifte funksioneer as nommae nomata. Juis die mens wat die Woord gelowig aanvaar, ervaar deur vaste belydenisformules dat hy behoort tot die menigte van hulle wat voor hom die skrif geïnterpreteer het. Hy is een 
"with the witness of the early church" (Niesel, 1980:54). Calvyn glo dat die suiwer belydenis 'n onberispelike lewe van bekering na vore bring (Van Itterzon, 1971:14). Die Reformasie aanvaar die vroegste belydenisskrifte (Apostolicum, Nicea en Athanasius - vgl. NGB art. 9) met die uitsluitlike doel om die gemeentes in geloof en lewe op te bou. Calvyn het die herders op huis- en skoolbesoek laat kontoleer of ouers en onderwysers hulle kinders in die Bybel en in die leer onderrig. Sonder hierdie voorkategese kon niemand aan die hand van 'n kategismus kom katkiseer en geëksamineer word nie (Van 't Veer, 1942:62,112,140,174). Daarmee het Calvyn die bewering van die Anabaptiste dat die kinderdoop persoonlike geloofsverantwoording en -belydenis uitgeskakel het, ontkrag (lbid:295; Kuyper, 1909:505). Om 'n geloofsbelydenis te aanvaar, mag nooit as die resultaat van Christelike opvoeding, die kroon op die arbeid van vader en moeder, leratar en dominee "of het met glans afgelegde eindexamen van de catechesatie" voorgeste! word nie (Velema, 1973:10). Die belydenisskrifte was ' $n$ besondere vorm van verkondiging wat tot 'n bewuste persoonlike keuse dwing (vgl. Green, 1970:151; Van 't Veer, 1942:289).

Om kortweg saam te vat: die Reformasie wou met belydenisskrifte niks anders doen as om die Heilige Skrif te bedien aan mense in nood nie. Hulle moes die volle "waarheid" van die Skrif omhels en daartoe moes die belydenisskrifte dien. Hulle moes met die volle Skrif rekenskap kon gee aan Rome en Wederdopers wat oënskynlik die Bybel met hulle selektiewe teksberoep teenoor "menslike belydenisskrifte" wou laat spreek. "By Calvyn adem kennis die intiem persoonlike geur van jada (ek weet), waarsonder geloof en godsvrug en 'n lewende verhouding met God nie moontlik is nie" (Schulze, 1988:27). Voor Kant die dualisme tussen kennis en geloof, die objektiewe en subjektiewe, die teorie en praktyk, ingevoer het, kon die leer werklik troos (Schulze, 1988:28; Dijkstra, 1980:47). Die belydenisskrifte het "die hele Skrif in sy volle samehang" aan die woord gestel (Engelbrecht, 1989:628 e.v.). So het die Drie Formuliere van Eenheid diakoniologies beskou, gedurende die Reformasie didaktiese, kategetiese, polemiese en pastorale funksies in 'n eksistensiële situasie verrig (vgl. Ibid:622).

\section{DIE GEBRUIK VAN DIE DRIE FORMUL.IERE VAN EENHEID}

Geloofsinhoude wat enersyds in kategismusse en andersyds in belydenisskrifte verwoord was, het kerkgemeenskappe in verskillende etniese en politieke bedelinge in die 16de eeu geïdentifiseer. "Zij herkenden elkander, en daarom erkenden zij elkaar in een consensus doctrinae ... die haar uitdrukking vind in de gereformeerde belijdenisschriften ... Zij waren niet nauw in hun ingewanden" (Van 't Spijker, 1974:52). Hulle 
het mekaar se reg erken om dieselfde geloof in verskillende belydenisskrifte uit te druk. Die Skrif moes egter in elke geval die enigste reël, rigsnoer, grondslag en regter in geval van verskille bly (Polman, s.j.:55-63). Die belydenisskrifte het ook waarheid teen dwaling gestel (Schulze, 1990(2):13). Geloof het konsekwensies vir die kerk (Van Genderen, 1977:17). Binding aan 'n belydenis maak kerk eers 'n kerk. Sonder die binding aan die belydenis kom die "hotelkerk" na vore (Coetzee, 1970:17). Die geloof wat die Drie Formuliere van Eenheid uitdruk, is nie antroposentries nie, maar teosentries. Dit funksioneer nie eensydig soos die moderne genitief-teologiëe (van bevryding ensovoorts) nie, stel nie probleme nie, maar wys "chaotisch pluralisme" af en gee op beginselvrae antwoord (Van Genderen, 1975:21).

Selfs verskillende belydenisskrifte (Nederlandse en Franse) kon dieselfde geloof uitdruk en kerke het daarin die innerlike kerkverband erken waarop hulle met mekaar saam op pad (sun-hodos, sinodale verbande) kon gaan (Coetzee, 1947:28-47; Spoelstra, 1989a:171, 297). Daar is fundamentele ooreenkomste tussen die NGB en Dordtse Kerkorde (vgl. Du Plooy; 1988:11). In ondertekeningsformuliere gee kerklike dienaars die versekering dat hulle die kerk as "eenheid in ware geloof" sal eerbiedig (Spoelstra, 1989a:5, 298-301; Schulze, 1990(10):10 e.v.). Gevolglik identifiseer die belydenisskrifte die geloofsgemeenskap ook na buite.

Nie-fundamentele verskille soos ten opsigte van die Engelse episkopalisme het een formele belydenisskrif onder al die gereformeerdes verhoed, maar eenheid is op die fundamentele aspekte van die geloof tussen nasionale kerkgemeenskappe erken (Van Itterzon, 1971:66; Polman, 1973:10, vgl. Spoelstra, 1989a:466). Verskeidenheid is gewaardeer so lank kontinuiteit in die Woord van God geleë is (Van 't Spijker, 1974:30). In die krisis van 'n ingrypende reformasie kon gewone mense die belydenisskrifte in "a popular movement" gebruik om geloof van individu na individu, van een gesin en gemeenskap na 'n ander tuit te dral (De Jong, 1968:6,13).

Die Drie Formuliere van Eenheid bied nie die ervaring, uitsprake en opinies van Christene of teoloë van lank gelede oor vrue van vroeër nie. Van die vroegste belydenisskrif, die Twaalf Artikels af tot en inet die Dordtse Leerreëls (1618), gaan dit om die inhoud van die Skrif. Die Formuliere wil die Woord bedien en dien. "Wij kunnen alleen die waarheid belijden die ons in ons hart zo raakt, dat wij die met ons gehele leven bedienen moeten ..." (Van Genderen, 1975:12; König, 1966:27 e.v.). Gelowiges wil met 'n belydenisskrif maar net sê wat die Skrif sê. Belydenis "is immers net'n belydenis, 'n erkenning, ' $n$ openlike na-sê in gebrekkige menslike taal van die waarheid ..." (Schulze, 1990(3):15). In die Drie Formuliere van Eenheid kom ons gelowige kerkwees na vore in wat ons op grond van die Bybel glo. 
Vanaf die 19de eeu kom die abstraksie "kerk as instituut" (Kuyper, 1909:209) na vore en verloor die kerk as geloofsgemeenskap "sy menslikheid" (Van Aarde, 1987:325, vgl. 1989:461). In dié opset kry die Drie Formuliere van Eenheid 'n bloot formele funksie soos ' $n$ vlag van 'n skip die land van sy herkoms aandui. Die verenigingsreg en kollegialisme gebruik soms die Formuliere van Eenheid in 'n grondwet (of kerkorde) om 'n "kerk" tot 'n selfstandige regspersoon te "konstitueer" (vgl. Spoelstra, 1989a:13 e.v.; 1990d).

\subsection{Die funksie van die Nederlandse Geloofsbelydenis (NGB)}

Guido de Brés het geglo dat die Skrif gelowiges verplig om in 'n konfessie hulle geloof te verwoord (vgl. Matt. 10:32; Mark. 8:38; Luk. 9:26; 1 Pet. 3:15 ens.). Confessio is 'n term uit die regsfeer wat aflê van getuienis beteken (Delleman et al, 1966:12). De Brés wou met die Nederlandse Geloofsbelydenis die "gemeen accoord" of getuienis van die ongeveer 100,000 gereformeerdes in België verwoord. Hy het dié belydenis in die nag van 1 tot 2 November 1561 oor die kasteelmur van Doornik gegooi om die landvoogdes te probeer oortuig dat die owerhede eenvoudige Skrifgelowige mense vervolg wat om des gewetenswil nie anders kan as om vir hierdie geloof te sterf nie. Die kerke het hierdie belydenis offisiëel te Armentiéres-(1563) en te Antwerpen (1565/66) onderskryf. (Delleman et al., 1966:7-9; Van Itterzon, 1571:60-65). Toe reeds moes ampsdraers die Nederlandse Geloofsbelydenis onderteken om eendrag en eenheid te verseker (vgl. NGB 32; Van Itterzon, 1971:66).

Die hart van die NGB is "de lofzang op het geheimnis van de liefde Gods in Jezus Christus" (Polman, 1973:8). Die NGB adem nie so sterk die persoonlike ek glo-taal (Dykstra, 1980:40) van die Heidelbergse Kategismus nie. Die NGB spits meer teologies toe op "reg bely", terwyl die Heidelbergse Kategismus by die reg bely ook dankbaarheid, reg lewe, lewenskunde gepaard met lewenskuns, opvang en weergee (Van der Leeuw, 1946:174; Engelbrecht, 1989:635-639). Die NGB sou dus meer in nakategese by verdieping van geloof gebruik word (vgl. GKSA, 1863:art. 13).

Die NGB bely in artikel 7 die sola scriptura-beginsel. Uit die argumentasie van die Herderlike Brief van die Ring van Graaff-Reinet in 1841 is dit duidelik dat die eenvoudige "Doppers" hulle op die belydenis in hulle reaksie teen die Evangeliese Gesangbundel van 1807 beroep het (Spoelstra, 1989b:64). Skrywer hiervan het tydens sy bediening een maal die NGB deurgepreek en baie waardering daarvoor in die gemeente gevind. Tog het die NGB baie minder opsigtelik indien wel in die gemeentes gefunksioneer. 


\subsection{Die funksie van die Heidelbergse Kategismus}

Frederik III van die Palts wou die Heidelbergse Kategismus vir volksonderwys aan volwassenes en vir kinders in die skole ontwerp sodat die hele volk - Lutherane en Calviniste - in reformatoriese geloof kon konsolideer en opgebou word sodat die hele nasie hulle doop verstaan (Van Itterzon, 1971:75). Frederik het self met betrekking tot die doel en tema van die Kategismus 'n persoonlike stempel afgedruk en kon dit "my Kategismus" noem (Wielenga, s.j.:9 e.v.). Op voetspoor van die Lutherse kerke het die prediking van die Heidelbergse Kategismus spontaan posgevat totdat die Dordtse Sinode in 1619 gereelde prediking van die Christelike geloof aan die hand van die Kategismus verorden hel (Spoelstra, 1989a:368 en 1990).

'n Opvallende persoonlike intieme aanslag kenmerk hierdie leerboek. Telkens prikkel die vraag "Wat glo jy van ..." sodat die antwoord 'n persoonlike oortuiging moet bely (Doekes in Dockes \& Deddens, 1963:8,10; Dykstra, 1980:40). Die Heidelbergse Kategismus het deur sy intrinsieke gehalte langs die weg van praktiese gebruik die status en karakter van geloofsbelydenis en Formulier van Eenheid verwerf. Hierdie produk van "een international oekumenischgereformeerd kerkleven" (Doekes, 1963:12) het in talle lande van Europa (Oberholzer, 1989:600-605) onder andere in Nederland, die godsdiens en kultuur onmiskenbaar gevorm. Die Heidelberger was in Suid-Afrika tot aan die begin van 19 de ecu feitlik dic enigste volkspedagoog en -kategeet. Oral waar die gebruik van die Kategismus egter afgeskaal is, het kerkverval ingetree (Doekes, 1963;13; Hanekom, 1951:177-181, 495 ens.).

Die onbestrede status van die Heidelbergse Kategismus moet toegeskryf word aan sy besondere inhoud, die "profound emphasis upon the gratitude or thanksgiving which the redeemed have for their salvation" (Heideman, 1988:7). Ursinus koester by die opstel van die Kategismus 'n diakoniologiese motief met "de zuivere en onbedorvene leer van de wet en evangelie, van de ware God, zijn wil, werken en vereering" omdat die Heilige Gees daardeur in die harte van die uitverkorenes werk om die kerk van Christus te vergader (Ursinus, 1886:1). Die volmaaktheid en suiwerheid van die wet en evangelie bewys die waarheid en goddelikheid van die leer en gee geloofsekerheid (Ibid:7-11) wanneer "zij onder het bereik komt van het verstand der jongeren en minder ervarenen" (Ibid:17). Die leer moet 'n rigsnoer wees om God te dien en eer, die lewe op koers te hou, bydra om die bose tot heil van kerk en staat te bestry en help dat preke beter verstaan kan word. "Voor de jeugd en pas beginnenden is immers een wijdlopig en uitgebreid onderwijs moeilijk en nutteloos." Derhalwe moet "het kort, eenvoudig en duidelijk zijn, zoo is de Catechismus" (Ibid:18). 
By hierdie mooi bedieningsgerigte aanpak het die opstellers nog nie oor die kennis van huidige empiriese en didaktiese kategetiek beskik nie sodat sommige die ongegronde stelling maak dat die Kategismus te teologies en abstrak opgestel is (Van 't Veer, 1942:284). Die Kategismus is seker te veel op volwassenes afgestem en raak nie altyd die taal, idioom en ervaringswêreld van die kind en selfs adolossent nie (Ibid:285). Gevolglik is al in die 17 de eeu probeer om die Kategismus en toepaslike Skrifbewyse met die oog op huislike en skoolopvoeding te gradeer. So het al vroeg 'n $A B C$-boekie (Borstius), Korthegrip (Faukelius) en 'n korter en langer Hellenbroek ontstaan. Die inkorting en vraeboekies het weer baie van die "skoonheid van die Kategismus" verlore laat gaan (Gerdener, 1978:183). Na die tuisopvoeding het 'n kort (gewoonlik veertiendaagse) amptelike kategese die volle Kategismus behartig. Daarop het 'n ondersoek plaasgevind wat tot die aflê van belydenis van geloof kon lei (vgl. Doekes \& Deddens, 1963:30-32,36; Kajajan, s.j.:97; De Villiers, 1957:121; Dijk, 1954:92 e.v.). Nadruk is in die huislike opvoeding (voorkategese) en in die amptelike belydeniskatkisasie gelê op vrae na die persoonlike oortuiging oor geloofswaarhede (De Wet \& Coetzee, 1943:90102).

Die Rasionalisme het mense laat glo dat kennis die Griekse ideaal van 'n goeie deugsame mens verwesenlik. Predikante aan die Kalap het al in die $18 \mathrm{de}$ eeu eie katkisasieboekies met 'n sterk verstandelike inslag ontwerp (vgl. Britz, 1990:32). Volgens die mode! van Kant waarin die objektiewe (leer) los van en teenoor die subjektiewe geloof (die mens), en teorie (dogma, belydenis) teenoor praktyk (bekering) gestel is, het die piëtisme die orde omgekeer om oor die subjektiewe te praat (vgl. Schulze, 1988:27; Dijkstra, 1980:46). Teen die middel van die vorige eeu het die Kortbegrip en Kategismus in die Sondagskool en selfs belydeniskatkisasie van die Kaapse Kerk begin verdwyn en het plattelandse gemeentes tevergeefs gevra om dit terug te bring (De Villiers, 1957:202-239. Vgl. Spoelstra, 1990c).

In die GKSA is op die platteland langer met die Kortbegrip en Kategismus is in die kategese volgehou. Verskillende predikante het handleidings vir hulle katkisasie saamgestel. So het die Kortbegrip van ds. W.J. Snyman sr. 'n kort oorsig oor die Drie Formuliere van Eenheid gegee en daarna is net die Kategismus behandel (Postma, 1910:755). Op dieselfde spoor beweeg Verklaring van die Heidelbergse Kategismus vir die katkisasie (Van der Walt, s.j.) wat tot 1936 ses herdrukke belewe. Die meeste kategismusvrae word ook met verwysings na die Skrif en NGB verklaar. Katkisasie met die Kategismus moes tot geloofsoortuiging en geloofsbelydenis lei. Die Handbock by die katkisasie (1925) in die N.G. Kerk het egter die hele Tien Gebooie by die leer oor die sonde en nie by die dankbaarheid nie behandel (Gerdener, 1938:181, 191-204, 319-332. Vgl. Sondagskoolkommissie, 1960:122-123). Hierin tree 'n subtiele verskuiwing van 
vertrekpunt ten opsigte van die Kategismus na vore. Die Kategismus leer dat dankbaarheid die Christen verplig om God volgens sy Wet te dien (vgl. Ursinus, 1886:16). Teen die 19de eeu is die aandag op die mens gevestig sodat die Wet gebruik word om die sonde wat sy mensbeeld (die goeie en deugsame) skend, voorop te plaas en die vergiffenis van sondes te benadruk. So verskuif die aksent van teosentriese geloof en godsdiens wat God dien, na antroposentriese geloof en soteriologiese godsdiens.

Wanneer die laaste Christelik-nasionale Skole teen 1920 deur die neutrale staatskool oorgeneem word, begin ' $n$ sinodale kategese in die GKSA al meer die Christelike opvoeding by die ouers oorneem. Met die oog daarop word Rooi- en Blouboekies ontwerp en kategese word op ' $n$ skoolpatroon ingerig waarin die "kerkleer" 'n vak naas die Bybel word (vgl. (GKSA, 1927:82 e.v.). Die sentralisasie van skole en kinders in koshuise laat die "kerk" met "katkisasieonderwysers" spoedig in die skoolpatroon opgaan en die Kategismus word in plaas van die kategetiese middel al meer as 'n vak om naas die Bybel te "leer" (vgl. GKSA, 1945:120-126 en 1967-1988; Spoelstra, 1990d). So bedien die Kalegismus nie meer die Skrif nie, maar word die Kategismus as belydenisskrif (van die kerk?) al meer objektief en los van die Bybel geplaas. Dogma en Bybel word geskei.

Op afgeleë plase was Die lleidelberger egter tot in die middel van hierdie eeu by uitnemendheid dié predikant en onderwyser van die gereformeerde Afrikaner wat baie min skool of eredienste kon bywoon. Die Kategismus was midjel par exellence in werklike geloofs- en gemeenteopbou. Die Heilige Gees het met die Kategismus aan talle eenvoudige gereformeerde mense kennis van en vertroue in die Skrifwaarhede gegee wat hulle soos "praktiese teoloë" sinvol elke dag op gewone lewensprobleme kon toepas. Die vermoë en weerstand van gereformeerdes teen metodisme, charismatici, sektes en selfs oppervlakkige prediking en godsdiens, was tot ongeveer 1950 goed bekend.

\subsection{Dic funksie van dic Dordtse l ecrrec̈ls (1618)}

Die uitsprake van die Dordse Sinode van 1618 wat met behulp van 17 kolleges van buitelandse teoloë gedoen is, dra veelbetekenend die naam van Canones van Dordt. Dit was waarskynlik die eerste omvangryke "formulier van eenheid" wat juis onderlinge konfessionele "onenigheid" wou betrek. Gevolglik gee dit uitspraak oor 'n aantal teologiese verskilpunte deur eers die Skrif teties te laat praat en daarna die Remonstrante paragraaf vir paragraaf antiteties te weerlê met die doel om die eenheid en opbou van die kerke in die ware geloof te dien (vgl. Van Itterzon, 1971:14). Die DLR spits toe op die troosryke leer van die verkiesing en verklaar hoe verlore mense tot geloof kom (Van Itterson, 1974:79-83; Klooster, 1968:52). 
Uit die aard van die saak het ons in die DLR met ' $n$ "theologisch tractaat" te doen wat, hoe getrou aan die Skrif ook al, vir die meeste mense 'n geslote boek bly (Van 't Spijker, 1974:19; Polman, 1973:8). In die belydenisskrif kom juwele voor (vgl. DLR 3 en $4: 11,12$ ). Tog word die DLR hoofsaaklik in die teologie gebruik om dwalings te bestry (bv. GKSA, 1982:57 t.o.v. EE3; Van Genderen, 1977:8 e.v., 11-17). Sodra teologiese aksente van God na die mens verskuiwe, raak die DLR dadelik onpopulêr en in onbruik (Snyman, 1972:3-16). Waar die Heidelbergse Kategismus gebruik is om die liggaam van die Here in die belydende gemeente sigbaar te maak (Van 't Veer, 1942:7 e.v.), is die DLR merendeel tot heil van die leer (ortodoksie) gebruik. Die DLR het minder as die Heidelbergse Kategismus en selfs die NGB 'n impak op die gewone gelowig- en kerkwees gekry.

\subsection{Samevatting}

Gedurende die Hervorming het sommige van ons moderne probleme met die belydenisskrifte nie bestaan nie omdat die leer van die Skrif persoonlike geloof bepaal het. Die Hervormers het nie soos mense vandag met die rasionalistiese dualisme tussen leer en lewe, kennis (as iets objektiefs) en geloof (as iets subjektiefs), geworstel nie (vgl. Schulze, 1988:27). Belydenisskrifte het gesê wat die Skrif sê (König, 1966:27 e.v.; 1982:361) en wat elke gelowige vir homself moet toeëien, in teenstelling met biblisiste wat hierdie belydeniswerk links laat lê (Wielenga, s.j.:21). Die Heidelbergse Kategismus konsentreer op die credo van die vroegste kerke, die Wet en gebed. Met hierdie sterk teosentriese en Christologiese opset het hierdie belydenisskrif die stempel van die Skrif op gereformeerde kerkwees en selfs op die politieke lewe afgedruk (vgl. Wielenga, s.j.:17). Die credo-karakter het hierdie leerboek en belydenis 'n ongeëwenaarde diakoniologiese instrument tot gereformeerde kerk-wees gemaak.

\section{GEBRUIK VAN BELYDENISSKRIFIE: IN AFSKEIDINGSBEWEGINGS GEDURENIDE DIE 19DE EEU}

Die 19 de ecu het met die Regleme'n vant die NHK' in 1816 van die kerk nie meer mense wat glo nie, maar 'n statiese struktuur, 'n wetlik-omlynde instituut vir mense gemaak (Spoelstra, 1986:4; Van Aarde, 1987). Belydenisskrifte het deel van die konstitusie geword wat die kerk identifiseer. Strukture wat formeel dieselfde belydenisskrifte het, sou dan suster-kerke wees (modelle van dieselfde fabrikaat). Daarmee het die Drie Formuliere van Eenheid die nuwe formele konstitusionele funksie bygekry.

Wanneer die Nederlandse Hervormde kerkbesture van bo af die ortodokse gemeentelike beweging (kerk as gelowiges) van De Cock wil hokslaan, verklaar die kerkraad van 
Ulrum op 13 Oktober 1834 "volgens Gods Woord in art. 29 van onze Belijdenis" die NHK as struktuur tot "de valsche Kerk" (Rullmann, 1916:147). Hierdie strategie verskil aanmerklik van Calvyn wat in 'n stryd oor die gemeenskap in die leer nog ware kerke onder 'n stelsel van korrupte kerkregering erken (Calvyn, 1951:331).

Kuyper werk in detail uit hoe artikel 29 NGB soos'n kaart by 'n padwaardigheidstoets vir' $n$ objektiewe kerkstruktuur gebruik moet word (1883:168) maar om die naam belydeniskerk te vermy, wil hy nie die "confessic ... als nota van de kerk" gebruik nie. Die konfessie is immers nie oorsaak (konstitusie) vir die kerk nie, maar "vrucht van de Kerk" (Kuyper, s.j.:227). Artikel 29 NGB is diakoniologies op die suiwer bediening van die gemeente (mense) gerig. Net die gemeente kan en moet die Woord in leer, diens en tug gehoorsaam. In die 19de en 20ste eeu is die belydenisskrifte dikwels as sjibolet gebruik om statiese kerkstrukture te beoordeel, te identifiseer, te tipeer of te etiketteer (Kuyper, 1883:103; Van 't Spijker, 1974:18, vgl. Spoelstra, 1978:25-30; 1986:6-9). Rullmann skryf drie werke $(1915,1916,1917)$ oor die stryd van 1820 tot 1886 in Nederland en verwys telkens in een of ander verband na die belydenisskrifte sonder dat hy oor 'n stryd oor belydenisskrifte of belydenisinhoud as sodanig handel. Die situasie herhaal hom in hierdie ceu binne die GKN met dié verskil dat die GKN altyd voorgegee het dat hulle die Drie Formuliere van Eenheid wou handhaaf (Van der Linde, 1986:20).

Die CGKN (Christelijke Gereformeerd Kerk Nederland) wat ds. Postma afgevaardig het, het die GKSA eers erken toe die GKSA volgens die skema van die CGKN die NIIK van die ZAR tot "valse kerk" verklaar het (Spoelstra, 1963:191 e.v.; 1986:7). Ds. D. Postma bring uit sy Nederlandse ervaring die belydenisskrifte pertinent in die "openlike verklaring" van die eerste Gereformeerde Kerk te Rustenburg op 14 Februarie 1859 na vore omdat dit met die Woord ooreenstem. Op sterkte van hierdie belydenisskrifte nooi die gereformeerdes in Transvaal almal wat hierdie geloof wil onderhou uit om met hulle in een kerkgemeenskap te lewe (Postma, 1905:145; GKSA 1862:art. 12; Ibid. 1963:art. 7).

Die GKSA verbind hulle uit die staanspoor om die Drie Formuliere van Eenheid as konsensus van hulle Skrifverstaan na te lewe en binding aan die belydenisskrifte kom in die GKSA veelvuldig voor: by onderlekeningsformuliere, aflê van geloofsbelydenis, doopvrae, attestasies, mandaat aan afgevaardigdes na sinodes, beperking van gesag in besluite van sinodes, ensovoorts (vgl. byvoorbeeld Spoelstra, 1989a: 189, 208, 298, 338 ens.). Talle verwysings na die Drie Formuliere van Eenheid (byvoorbeeld in afvaardiging na sinodes) het grootliks funksie- en betekenisverlies ondergaan en 'n formaliteit geword. In die reël weet kerklike dienaars en deputate skaars dat hulle aan die Drie Formuliere gebind is terwyl talle ook slegs met die Kategismus enigsins vertroud is. 
Die GKN bied 'n tragiese voorbeeld van wat die gevolge van so 'n onwerklike en formele gebruik van belydenisskrifte onder predikante en teoloë kan meebring. Die een oomblik kon 'n teoloog nog rustig sê:

In onze kerken is er geen distantic tusschen het oude belijden der vaderen en het levend belijden in het heden. De Heidclbergsche Calcchismus op de catechisatic onderwezen en elke Zondag in het midden der gemeente verklaard, is ook heden nog het troosbock der gemeente. De Confessie op mannen en jeugdverecnigen besproken, is niet geheel onbekend. De Dordtsche Lecrregels werden weinig gelezen. (Polman, s.j.:97)

Wanneer ' $n$ onderwerp daaruit egter aan die orde kom, is daar lewendige belangstelling voor. Die belydenis moet uitgebou word (Polman, s.j.:97). Die volgende oomblik noem 'n ander teoloog, Kuitert, egter die belydenisskrifte formuliere van "blijvende onenigheid". "De tijd dat formulieren (lees: formuleringen) kerkelijke eenheid konden vestigen of redden is voorbij" (vgl. Van (ienderen, 1975:11 i.s. Augustyn). Om iemand "trou" aan die belydenis te bevind, is maar net 'n naiewe manier om te sê hy stem met jou saam. Konfessies is niks werd omdat dit dialoog die grond in boor en daarom moes die GKN selfs nie eers met "een nieuwe belijdenis" begin nie (Kuitert, 1972:110-115).

Die "Geloofsgetuigenis" as bondiger belydenis in eietydse idioom, wat proff. Berkouwer en Ridderbos in opdrag van die Sinode van die GKN opgestel het, het nie geslaag nie (Van Genderen, 1975:11). Daar is tans moontlik ook in SA iets van 'n "belydenisfobie" sigbaar (Coetzee, 1970:24). Die ironie is dat konfessies in die verlede nie corsaak nie maar vrug van verdeeldheid was (Schulze, 1990(3): 15).

"Ongetwijfeld heeft een confessionele theologie een sterke band aan het verleden." Ouderdom alleen is egter geen afdoende getuienis om die doodvonnis oor die belydenis te vel nie (Van Genderen, 1975:16 e.v.). Voordat iemand die ou belydenis verwerp, sê Van Ruler, "moet men eerst de grootsheid ervan ondergaan. Men moet de muziek er weer in horen zingen" (Van Genderen, 1975:18). Word belydenisskrifte egter so bedien dat gelowiges die musiek van die Woord daarin hoor speel?

\section{HET EIETYDSE KERK-WIES NOG; BELYDENISSKRIFTE NODIG?}

Weerstand teen belydenisskrifte hang saam met ' $n$ bepaalde instelling, ' $n$ bepaalde basisgeloof. Piëtisme identifiseer godsdiens op voetspoor van Schleiermacher slegs as 'n gevoel van absolute afhanklikheid (Tillich, 1968:392). Elke mens en elke tyd is uniek en daarom word nie na geloofsekerheid in vaste Bybelse formules gevra nie (Heideman, 1988:9) maar na sekerheid in eie ervaring. Die Piëtisme vra in reaksie 
teen die Rasionalisme 'n ondogmatiese Christendom, eenheid bo geloofsverdeeldheid, "Christentum der praktischen Tat ohne bestimmten Dogmenglauben" (Lohse, 1963:10; vgl. Aulén, 1960:60). Die Piëtisme is met 'n vroom geestelike instelling van geloofsekerheid tevrede (Aulén, 1960:61). Onder invloed van Barth maak sommige mense 'n skerp skeiding tussen 'n statiese belydenisstand (belydeniskerk) en 'n dinamiese belydenisdaad (belydende kerk) (Polman, s.j.:97). Die Liberalisme of vrysinnigheid sluit wêreldwyd aan by die idee van 'n Christendom bo geloofsverdeeldheid (d.w.s. sonder vaste belydenisskrifte en dogma). (Vgl. Hanekom, 1951: 177; Van Itterzon 1971:58.)

In die volgstroom van die Liberalisme word belydenisskrifte verwerp as werktuig van 'n "bazige kerk" (Kuitert, 1972;70) wat verdruk en tiranniseer. Hoe vryer die menslike rede gelaat word, hoe groter welvaart kan mense belewe (Niebuhr, 1950:253). 'n Nuwe belydenis sal die maagdelike geboorte, wederkoms, ensovoorts uit die credo moet weglaat om "een belijden voor onze tijd" te kan wees (Kuitert, 1972;111).

Rewolusie is per definisie anti-histories en historiese belydenisskrifte het daarin geen plek nie. Van Marx is geleer dat "religious symbolism ... is the invention of the ruling classes to prevent the masses from seeking fulfilment in this life ..." (Tillich, 1968:482). Die koninkryk word nie in dogmas sigbaar nie, maar waar armes ryk gemaak en gevangenes losgelaat word (Heideman, 1988:10). Gevolglik dring hierdie kairos aan op 'n status confessionis (Smit, 1984;21). Nuwe tipe belydenisse soos die Kairos-dokument (ICT, 1985 vgl. IRS, 1987) en Road to Damascue (ICI, 1989) sien die lig. Dié "belydenisse" berus op sosio-politieke analises vanuit 'n konteks deur middel van Marx se dialektiek en probeer nie eers uit die Bybel teologiseer nie.

In die lig van die verwarring kan 'n mens verstaan dat die CRC in die VSA vandag nie "in a confessional mood" is nie. "Confessional documents at their best seem to me declarations of things which churches feel compelled to say ... Many of us operate with confessional documents that are exclusively pre-modern" (Mouw, 1984:2). Uit dieselfde kerklike kring vind Klooster onder teologiese studente min "warm, positive experiences from the past", selfs met die Kategisnus. "In my own case, it was only detailed and careful analysis of the Ileidelherg Catechism that moved me from lukewarmness to enthusiasm for this jewel ..." (Klooster, 1977:26).

Die wyse waarop die belydenisskrifte aangebied, gebruik en mee omgegaan word, moet waarskynlik ernstig gehanteer word. Kinders vind dit soms "erg moeilijk" (Doekes \& Deddens 1963:5), terwyl veronderstel word dat hulle met die belydenisskrifte heel persoonlik en intiem hulle geloof bely (vgl. Van Itterzon, 1971:16). In Engeland kon geen reaksie op die religieuse simbole van die tradisie opgewek word 
nie. Mense (selfs gereformeerde teoloë!) wat van een kerk na 'n ander oorgaan, het geen probleem met die belydenis en die funksie van die belydenisskrifte nie (vgl. König, 1977:53 e.v.). Watter plek neem die belydenisskrifte nog by die gereformeerde mens vandag in waar hy hom in sosiale strukture en menslike situasies moet aktualiseer (vgl. Tillich, 1968:484; Polman, s.j.:93)? Het die "belydenisstand" in die Drie Formuliere van Eenheid na "belydenisstilstand" gelei (vgl. Van 't Spijker, 1974:51; Polman, s.j.:97)?

Die :tandag het van wat $j y$ glo (op sterkte van die Heilige Skrif) verskuiwe na wat jy doen (op grond van jou geloof). Uit die Rasionalisme het die valse teenstelling tussen teorie (dogma) en praktyk die geloof agterhaal (vgl. Schulze, 1988:28).

Waar het op aankomt, is het leven! Laten wij met elkaar goed en Christelijk leven, dan kunt u alle lecr en dogma's cadeau krijgen. En de slagginnen zijn overbekend: De lecr verdeclt en het leven verenigl. En: niet de leer, maar de Heer (Van lterzon, 1971:57).

Indien ons na die publikasies van die SA Werkgemeenskap vir Praktiese Teologie kyk, (vgl. Smuts, 1986-1988) merk ons dat die belydenisskrifte in die kerklike bediening en sogenaamde gemeenteopbou geen aandag geniet nie - dit word waarskynlik net as iets vir kategese en institutêre identifikasie gereken. Selfs 'n artikel wat oor pastoraat in diens van "eenheid van die kerk" handel (Snyman, 1988:66-75), verwys nie na die belydenis nie. 'n Artikel oor die doop en die belydenisskrifte is hierop 'n uitsondering (Dijkstra \& Van der Walt, 1989:22-34). Skynbaar loop die muur van Berlyn vandag so skerp tussen teorie (dogma) en praktyk deur dat "praktiese teologie" eeue ver van belydenis moet bly om prakties te wees. Pragmatisme, die vraag na wat werk, het in baie opsigte die waarheids- en geloofsvraag vervang.

Studies aan die PU vir CHO toon aan dat die tradisionele, belydend-konserwatiewe Afrikaner tot ' $n$ formeel-konserwatiewe Afrikaner ontwikkel wat konserwatisme as sekuriteit aangryp in sy soeke na eer en materiële voordele. Wanneer hiermee saam die innoveerders wat die tradisie verafsku en met nuwe dinge wil eksperimenteer, sowel as die liberale groep wat geen norm buite die mens self erken nie, in ag geneem word, het die tradisionele gereformeerde Afrikaners reeds in die minderheid geraak (Boshoff, 1989,1990). Aan die ander kant bring dieselfde navorsing onder diensplig. tiges uit gereformeerde huise weer sterk verwyte na vore waarin hierdie manne hulle kategetiese onderrig as nutteloos, swak en ontoereikend bestempel. 'n "Funktieverlies van de kerk" (Van 't Spijker, 1974:58) word as 't ware by hierdie jongmense ontbloot. Hulle verlang nie na spesiale kursusse oor seks en spesiale groot sake nie, maar soek na insig in en begrip van eenvoudige geloofswaarhede (vgl. Boshoff, 1989 en 1990). As die kategese die belydenisskrifte reg toepaslik bedien het, moes die behoefte nie na 
vore gekom het nie.

By al die verwarrende godsdienstige strominge het alleen die laaste paar dekades nog minstens ' $n$ twintigtal teologieë bygebring 'n Gelowige kan vandag eenvoudig nie sonder "'n bepaalde sleutel" die ryke inhoud van die Woord ontsluit nie (König, 1977:47 e.v.). Die belydenis funksioneer egter in gemeentes op so 'n lae vlak dat selfs predikante nie die belydenis ken nie. Lidmate wat oorgaan van een kerk na 'n ander dink aan 'n kerkinkopie maar nie aan belydenis en belydenisskrifte nie (vgl. König. 1977:53). En tog is belydenis van geloof in God die "vanselfsprekende deel van die lewe van die volk van God" wat die "lewe van die kerk bepaal" (Pont, 1981b:2)

\section{SAMEVATIING}

Die belydenisskrifte moet die geloof verwoord wat met Christus verenig, die Bybelse leer van dwalinge onderskei, geloof binne die gemeente kan oordra (kontinueer) en ander van buite tot "geloof" en so in die gemeente bring, die akkoord van gemeenskap of "eenheid in geloof" (eenheid van die kerk, HK, Sondag 21) verwoord, ensovoorts (vgl. Potgieter, 1981:84; Pont, 1981a:6; König, 1977:51). "Numerieke een-heid van belydenisskrifte" is nie absoluut nodig nie. Met "vele belydenisskrifte" het gereformeerdes "selfs groter instemming" met mekaar gehad as die Lutherane (Van der Westhuizen, s.j.:650). Die hele belydenis is selfs by ekumeniese gesprekke ter tafel (Du Ioit, 1965:79). Ondat elke wetenskap op voorveronderstellings berus, funksioneer belydenis as norm om te teologiseer (Van Genderen, 1975:14; Buytendach; 1971:5). Belydenis is "spreekregel der kerk ... de grammaticale regel voor de taal van de prediking" (Van Ruler, 1954 - in Van Genderen, 1975:9; Potgieter, 1981:92).

Al die lewensbelangrike funksies van die belydenis rus op een been: as die belydenis die Heilige Skrif weergee, dit wil sê as die Skrif daarin praat, bly die belydenis "altijd jong en levend en hoogs aktucel" (Polman, s.j.:102).

Die belydenisskrifte dra egter nie dieselfde karakter nie en word nie vir dieselfde doel gebruik nie. Die Credo (Twaalf Artikels) wat die groot historiese feite bely, funksioneer vandag nog in die liturgie en deur middel van die Heidelbergse Kategismus in kategese en in die mond van gereformeerdes wat hulle geloof teties moet verwoord of antiteties moet verdedig (vgl. Van Genderen, 1975:13). In goeie gereformeerde prediking funksioneer die Kategismus nog as agenda vir gemeentebou om die Bybel oor hoofsake van die geloof te laat praat (Spoelstra, 1990a; 1989a:369). In swak prediking word die Skrif onder die noemer kategismuspreek of deur verwaarlosing van die leer monddood gemaak. Die driedeling van die Kategismus is selfs vir evangelisasie (sending) bruikbaar om die Bybelse kerugma weer te gee (GKSA, 1988:368). 
Die Nederlandse Geloofsbelydenis vul kategese aan, maar by wyse van afwisseling kan die Christelike geloof ook stelselmatig daarvolgens gepreek word. Die Dordtse Leerreëls is diakoniologies minder bruikbaar, meer op bepaalde leerstukke toegespits en vervul gevolglik 'n meer "spesialiteits"-rol.

Hoewel die geloof wat mense bely die kerk bepaal (Pont, 1981b:2), kan dit gebeur dat gelowiges bepaalde dele van hedendaagse konfessies soos byvoorbeeld die kinderdoop onder bepaalde voorwaardes, verwerp "sonder dat dit heil in gedrang bring" wanneer die sondaar nie sy verbond met Christus verbreek het nie (König, 1977:55; vgl. Spoelstra, 1989a:302, 320, 392). Belydenisskrifte is nie vir ketterjag bedoel nie (Botha, 1981:42). Die skeuring in die GKN tussen 1942-1944 bewys hoe onder die noemer belydenishandhawing sondige selfhandhawing kan plaasvind (Van Genderen, 1975:7).

Die amptelike opdrag om oor die belydenisskrifte (as iets vreemds?) te skrywe, herinner aan die Sinode van 1942 wat kragtig oor "huiskatkisasie" wou getuig (GKSA, 1942:34-42) op 'n tydstip toe gesentraliseerde skole, koshuise en sinodale katkisasie die doodsklok oor huiskatkisasie gelui het. Dieselfde Sinode sien die ouers uiteindelik net as "behulpsels" (GKSA, 1942:41) vir 'n Sondagskool wat "kerkkatkisasie" genoem word. Op die skoolpatroon word die belydenis 'n vak naas die Bybel om te bestudeer (vgl. GKSA, 1942:42-45, 1967-1988; Spoelstra, 1990c). Daarmee verander die karakter van kategese. Die aksent verskuif van die amptelike onderrig wat 'n leraar met die Kategismus uit die Skrif met die oog op belydenis van geloof gee, na onderwys en opdoen van kennisinhoude waarvan die Kategismus een vak is omdat die kerk dit onderskryf. Die leer van die kerk (as instituut) het naas die openbaring in die Bybel te staan gekom. Gevolglik word die sogenaamde kategismusprediking al meer willekeurig nagelaat sonder om die kerkordelike akkoord in artikel $68 \mathrm{KO}$ ter sprake te bring.

Die teologie van Schleiermacher verslaan vandag sy tienduisende: nie die leer nie, maar die ervaring van geloofsekerheid, nie geloof as belydenis nie, maar geloof as persoonlike ervaring van 'n "schlechtsinniges Abhänklichkeitsgefühl"! Die Bybel gee nie inhoud om te glo nie, maar geloofservaringe van geloofshelde en mense moet gebou word tot byvoorbeeld die geloofservaring van Paulus. Met piëtisme en eksemplariese biblisisme kan die belydenis hoogstens in die Twaalf Artikels oorlewe. Al die ander belydenisskrifte hoort in die argief tuis. Wanneer 'n belydenisskrif as "kerklike eiendom" of ter wille van tradisie doel en leerstof op homself geword het, kan dit alleen onder'n grafsteen voortlewe.

Ons moet die feit onder oë sien dat die Drie Formuliere van Eenheid al minder deur individuele gelowiges, huisgesinne, kerk (gemeente) en selfs teolö̈ geken en gebruik 
word. Wie betekenisloos die begrip kerk gebruik en omskryf, ken gewoonlik nie die belydenisskrifte nie. "Verbondsoutomatisme" moet nie die persoonlike eenheid met die belydenis uitskakel nie (Velema, 1973:19). Geloofsbelydenis en geloofsekerheid is per slot van sake uitsprake oor God en sy werk in ons (Joh. 16:13, 17:3 ens.). Bely is om agter die Gees aan te sê wat God in die Skrif vir jou en ander gelowiges persoonlik en saam gesê het (Van Genderen, 1975:230). "Gemeentebou" kan dus nie sonder geformuleerde geloof in die belydenisskrifte plaasvind nie.

Indien rasionalisme, subjektiwisme en biblisisme die slag teen die belydenisskrifte verder gaan wen, verloor ons in die woorde van Van Ruler "een stok om op te staan, een staf om op te gaan en een stem om het loflied te zingen" (Van Genderen, 1975:13).

\section{BIBI .IOGRAFIE}

AUl.iN, (j. I)(6). The failh of the Christian church. Philadelphia : Muhlenberg.

BEUKES, M.J. dP. 1987. Vernuwing van dic ercdicns. Praktiese Teologie in SA, 3:1-33.

BOSHOFF, H. 198\%. Dic kerk en dic Negentigerjart. Potchelstroom : PU vir CHO. Instituul vir Tockonsstudics.

BOSHOFF, I1. 1990. Samelewingsveranderinge en die Kerk in die Negentigerjare: moontlike implikasics. Potchelstroom : PU vir (HO). Instiluut vir Tockomsstudies.

BOTHA, S.J. IO81. I Die helydenis en kerkregtelike verband in die Nederduilsch Hervormde Kerk van Afrikil. Henonnde Teologrese Sucdics, $38(2$ \& 3):30-44.

BRITZ, R.M. 19(0). Dic kerkhisloriese belang vir dic 'Korle Schets der Goddelijke Wacrheden', 'n katkisasichandboek vir dic Kataps-Hollandse Kerk uil die 18de eeu. Acto Theologica, 10(1):23-40.

BUYTENDACH, F.W. 1971. (iedragspraktyke t.o.v. die cenheidstruktuur: Skrif - belydenisskrifte ondertekeningsformulice, kerk in die nuwe Gereformeerde tcologic in Nederland. In die Sknflig, 5(19):3-17.

CALVYN, J. IOSI. Dic Institusic van Callyn. Weergegec deur A. Duvenage. Blocmfontein : Sacum.

COETZEE, J.V. 1947. (ieskicdenisversaking. Revisic van 'n "gekorrigecrde" brosjure van prof. dr. S.P. Engelbrecht. Polchclstroom : KJBF.

COETZEE, P.J. 1970. Dic binding aan dic konfessic. In die Skriflig, 4(16):9-27.

CONZELMANN, H. 1\%(6). On the analylsis of the confessional formula in 1 Corinthians 15:3-5. Interpretarion. A Jounual of Bible and Theologn, 20(1):15-25. Jan.

DE JON6, P.Y, 1\%68. The rise of the Reformed Churches in the Netherlands. (In De Jong P.Y. $c d$. Crisis in the Reformed (hurches. Michigan : Reformed Fellowship. p. 1-21.)

DE VILlters, D.W. 1957. Dic kategese in dic Ned. (ieref. Kerk in Suid-Afrika. Potchefstroom : Pro Regc.

DE WET, C.J.H. \& COETZEE, J. CHR, 1943. Dic beginsels, melode en geskicdenis van dic kategelicse onderwys. Kaapslad: Nasionale Pers.

DELLEMAN, T.II. BESSELAAR, A.T. c.a. 1966. Altijd bercid tot verantwording. Kort commentaar op Ned. (Belox)fsbelijdenis. 2de druk. Aalten : De Graalschap.

DIJK, K. 1954. De dienst alan de kerkjeugd. Kampen: Kok.

DIJKSTRA, H. 1980. Die aard van die persoonlike toespitsing van die heil in die Hcidelbergse Katlegismus ('n steckproef). Ih die Skriflig, 14(56):40-53. 
DIJKSTRA, H. \& VAN DER WALT, J.J. 1989. Dic religieuse betekenis van dic doop in die belydenisskrifte, veral in die Heidelbergse Kalegismus. In die Skriflig, 23(\%0):22-34.

DODD, C.H. 1\%66. The Apostolic preaching and its developments. London: Hodder and Stoughton.

DOEKES, L. \& DEDDENS, D. 1963. Vierhonderd jaar Heidelbergse Calechismus. Amersfoort : Comité Herdenking Heid. Cal. 19.1.1963.

DU PLOOY, A LE R. 1988. Dic verband Iussen dic Skrif, Konfessic en Kerkorde. Potchefstroom : PU vir $\mathrm{CHO}$.

DU TOIT, S. 1965. Tussen verstarring en verwarring. Tradisie belydenisskrif. Ned. Geref Teologiese Tydsknf, 6(2):75-80.

ENGELBRECHT, B.J. 1989. 'n Vergelyking tussen die tcologie van die Nederlandse Geloofsbelydenis en dic Heidelbergse Kategismus. Hervonde Teologiese Studies, 45(3):626-644.

(;ERDERNER, G.B.A. 1938. Handbock by die katkisasic. Kaapstad : SA. Bybelvereniging.

GEREFORMEERDE KERKE IN SUID AFRIKA 1862-1988. Handelinge van Sinodes.

CKSA

kyk

GEREFORMEERDE KERKE IN SUID AFRIKA

GREEN, M. 1970. Evangelism in the carly church. Grand Rapids : Ecrdmans.

HACENBA(.H, K.R. 1880). A history of Christian doctrines. Edinburgh : Clark.

HANEKOM, T.N. 1951. Dic liberale rigting in Suid-Afrika. Stellenbosch : CSV-bockhandel.

HEIDELBER(ISE KATEGISMUS.

HEIDEMAN, P. 1988. Old confussions and niw testimuny. The Refonned Joumal, 38(8):7-10. Aug.

ICT

kyk

INSTITUTE FOR CONTEXTUAL THEOLOGY

INSTITUTE FOR CONTEXTUAL THEOLOCYY 198\%. The road to Damascus. Skolaville Uitgewers.

INSTITUTE FOR CONTEXTUAL THEOLOGY 1985. Kairos-Dokument. Braamfontcin : Kairos Theologians.

IRS. 1987. 'n Reformatoricse kommentaar op dic Kairos-dokument. Polchefstroom : PU vir CHO. F1. Nrs. 231, 232.

KAJAAN, H. s.j. Het Grote Synode van Dordirecht in 1618/19. Amsterdam : De Standaard.

KLOOSTER, F.H. 1968. The doctrinal deliverances of Dort. (In De Jong P.Y. ed. Crisis in the Reformed Churches. Michigan : Reformed Fellowship. p. 52-94).

KLOOSTER, F.H. 1977. Theology, confession and the church. (Church and theology in the contemporary world. Grand Rapids: Reformed Ecumenical Synod. p. 21-38).

KONI(;, A. 1966. Die Heilige Skrif in die Drie Formuliere van Enighcid. Ned. Geref. Teologiese Tydskrif, $7(1): 21-29$.

KÖNIG, A. 1977. Teologiese en konfessionele pluraliteit en pluriformiticl. Theologia Evangelica, $X(1): 47-57$.

KÖNIG, A. 1982. Ekumenicse Teologie. (In Eybers H. e.a. Inleiding in dic Teologic. Pretoria : N(; Kerkbockhandel. p. 374-382.)

KUITERT, H.M. 1972. Om en om. Een bundel theologic en geloolsberinning. Kampen : Kok.

KURTZ, J.H. s.j. Leerbock der Kerkgeschiedenis. Utrecht : Kemink.

KUYPER, A. 1883. Tractaat van de Reformatic der Kerken. Amsterdam : Hoveker.

KUYPER, A. 1909 . Encyclopaedic der Heilige Godgcleerdheid. Deel III. Kampen ; Kok.

KUYPER, A. 1911. Onze Eercdienst. Kampen : Kok

KUYPER, A. s.j. Diclalen Dogmatick. Locus de Salulc, Ecclesia, Sacramentis. Tweede Druk. Kampen Kok.

LOIISE, B, 1963. Epochen der Dogmengeschichtc. Stullgarl : Kreuz-Verlag.

MOUW, R.J. 1984. As we sce it. The Refonned Joumal, 34(5):2-3. 
NEDERLANDSE GELOOFSBELYDENIS.

NEL, F.P.J. 1981. Die plek en funksie van dic geloofsbelydenis in dic erediens. Pretoria. (Proefskrif (D.Th.) - UP(Afd. B).)

NIEBUHR, REINDAL. 1950. The relevance of reformation doctrinc in our day (In Arndt EJ.F. ed. The herilage of the Reformation. New York: Smilh. p. 249-264).

NIESEL, W. 1980. The theology of Calvin. Michigan : Baker Book House.

(JBERHOLZER, J.P. 1989. Dic Heidelbergse Kalegismus in sy eerste jare. Hervormde Teologiese Studics, 45(3):598-610.

POLMAN, A.D.R. 1956. Belijdenisschrift. (In Grosheide, F.W. Van Itterzon, G.P. red. Christelijke Encyclopedic. Deel 1. Kampen: Kok, p. 551 e.v.).

POLMAN, A.D.R. 1973. De outoritcit van de belijdenis. In die Skrifig, 7(27):6-11.

POLMAN, A.D.R. 1978. De belijdenis in de crisis. Reformasie en Rewolusie. Potehefstroom: PU vir CHO. IBC F3 $(2,1974): 67-77$.

POI.MAN, A.D.R. s.j. Onze Nederlandsche (Geloofsbelijdenis. 4 dele. Franeker : Wever.

PONT, A. 1981a. Die historiese aglergronde van ons kerklike reg. Preloria : Kiltal.

PONT, A. 198Ib. Dic belydenis in historicsc verband. Henonnde Teologiese Studies, 38(2):1-29.

POSTMA, D. 1905. De geschiedenis van de stichling en ontwikkeling der Gereformeerde Kerk in ZuidAfrika. Paarl: Paarlsc Drukpers.

POSTMA, W. 1910. Calcchisatic-Handbockje. Blocmfonlcin : Nasionale Pers.

POT(;IETER, P.C. 1981. Bediening en belydenis. Bediening en bedienaar in die kerk van Christus, OVSS $1(1): 80-93$.

RINZEMA, J. 1900. De kerk lijkı soms op ecn warenhuis. Centraal Weekblad : Aug., $24: 8$.

RULLMANN, J.C. 1915. De strijd voor kerkherstel in de Nederlandsche Hervormde Kerk der XIXe Ecuw. Amsterdam : Kirchner.

RULlMANN, J.C. 1916. De Afscheiding in die Nederlandsch Hervormde Kerk der XIXe Eeuw. Amsterdam : Kirchner.

RULLMANN, J.C. 1917. De Doleantic in de Nederlandsche Hervormde Kerk der XIXe Eeuw. Ainstcrdam : Kirchncr.

SCHULZE, L.F, 1988. Dic Katcgismusprediking in dic krisis. In die Skriflig, 22(88):24-31.

SCHULZE, L.F. 1990. Dic Gereformecrde belydenisskrifte. Die Kenkblad, 7.2.90 to 20.6.90. 10 artikels"

SMIT, D.J. 1984. 'n Oomblik van waarheid: opstelle rondom die N.G. Sending-kerk se afkondiging van 'n status confessionis en die opstel van ' $n$ konsepbelydenis. Kaapstad : Tafelberg.

SMUTS, A.J. red. 1986-1988. Praktiese Teologie in Suid-Afrika. Transvaal. NG Kerkbockhandel. Nrs. 1 1016.

SNYMAN, Ph. 1972. Die Dordse Leerrecils ... bestry en bevestig. In die Skriflig, 6(23):3-16.

SNYMAN, T.M. 1988. Die pastoraat in dicns van dic eenheid van die Kerk. Praktiese Teologie in SuidAfrika, 5:66-75.

SNYMAN. W.J. 1948. Die gebruik van die woord "kerk" in die nuwe Testament. Potchefstroom : Teologiese Skool.

SNYMan, W.J. 1977. Nuwe en ou dinge. Uit die skat van die koninkryk. Potchefstroom : Pro Rege.

SONDAGSKOOLKOMMISSIE, GEFEDEREERDE NGK IN SA. 1960. Dic Katisasiebock. Bloemfonicin : Sondagskool-bockhandel.

SPOELSTRA, B. 1963. Die Doppers in Suid-Afrika 1760-1899. Kaapstad : Nasionale Pers.

SPOELSTRA, B. 1986. Hel ons kerk-wecs in slruklure gestol? In die Skriflig 20(80):4-17.

SPOELSTRA, B. 1989a. Gereformecrde kerkreg en kerkregering. 'n Handboek by die Kerkorde. Hammanskraal : Hammanskraalse Teologicse Skool.

SPOELSTRA, B. 1989b. Secession and the Reformed Churches in South Africa. In die Skriflig, 23(92): $60-80$.

SPOELSTRA, B. 1990a. Die sogenaamde kalcgismuspreck. Diklaat. Potchefstroom : Teologiese Skool. 
SPOELSTRA, B. 1990b. Het opvoeding ons kalegese uitgeboer? Die Kerkblad, 47.

SPOELSTRA, B. 1990c. Historiese Kategetick. Diktaat. Teologiese Skool Potchefstroom.

SPOELSTRA, B. $1990 \mathrm{~d}$. 'n Konkrete en strukturele ordeningsmodel vir kerke oor volks- cn taalgrense heen. In die Skriflig, 24(4) : 353-377.

SPOELSTRA, B. 1978. Calvyn en die grense van die kerk. In die Skriflig 12(45):20-37.

TILLICH, P. 1\%68. A history of christian thought: from its Judaic and Hellenistic origin to existentialism New York : Simon and Schuster.

URSINUS, Z. 1886. Verklaring op den Heidelbergschen Catechismus. Vertaling C. van Proosdij: Kampen : Zalsman.

VAN 'T SPIJKER, W. 1974. Eenheid in verscheidenheid? De identiteitscrisis binnen de Gereformeerde Gezindte. Kok: Kampen.

VAN T VEER, M.B. 1942. Catechese en catechetiche stof by Calvyn. Kampen : Kok.

VAN AARDE, A.G. 1987. Gedagtes oor die begin van die kerk, 'n geskiedenis van versoenende verskeidenheid. Hervornde Teologiese Studies, 43(3):325-351.

VAN AARDE, A.G. 1989. 'n Nuwe-Testamentiese begronding van die eenheid van dic kerk en die eis om kerkeenheid vandag. Henomide Teologiese Sudies, 45(2):461-475.

VAN DER LEEUW, S. 1946. Liturgick. Nijkerk : Callcnbach.

VAN DER LINDE, G.P.L. 1975. Dic huidige stand van die belydenis in die GKN. In die Skriflig, Y(33):32-39.

VAN DER LINDE, G.P.L. 1986. Dic Jolcansic 1886 - 'n oorwinning of intermezzo. In die Skriflig. $20(80): 18-24$.

VAN DE POL, W.H. 1931. Liturgic. Zeisl. Plocgsma.

VAN DER WALT, J.G.H. s.j. Verklaring van die Heidelfergse Katcgismus vir dic katkisasie. Middelburg KP : Die Middcllander.

VAN DER WESTHUIZEN, H.G. s.j. Dic belydenis en vernuwing of hernuwing. Henvomde Teologiese Studies, 38(2) \& 62-76.

VAN GENDEREN, J. 1971. De reformatorische belijdenis in discussic. 's Gravenhage : Willem de Zwijgerstichling.

VAN GENDEREN, J. 1975. Confessic en Theologic. Kampen : Kok.

VAN GENDEREN, J. 1977. De continuiteit van geloof en kerk. Kampen : Kok.

VAN ITTERZON, G.P. 1971. Belijnd belijden. Kok : Kampen.

VELEMA, J.H. 1973. Blijven belijden. Amsterdam : Buijlen en Schipperheijn.

VON (jÜNTER, Haule. 1985. Funktion und Interpretation urchristlicher Bckenninissätze. Theologischo Literaurzeitung, 110(11):786-794.

WIELEN(;A, B. s.j. Onze Catechismus. Deel i. Kanpen : Kok.

ZUIDEMA, S.U. s.j. Van geloof tol geloof. Francker : Wever. 
Page not available 
Page not available 